\title{
The U.S. Midcontinent: A New Frontier for Mineral Exploration
}

\author{
by Walden P. Pratt and Paul K. Sims
}

The north-central U.S. Midcontinent is underlain by a considerable thickness of sedimentary rocks, mostly Paleozoic, which lie upon a heterogeneous basement of Precambrian granitoid and metamorphic rocks. This article describes a representative sample of Midcontinent geology and explains why the authors believe this region is a "new frontier" for mineral exploration and discovery.

\section{Introduction}

The U.S. Midcontinent includes broadly the entire region from the Appalachian Mountains west to the Rocky Mountains, and from the Great Lakes to the Gulf of Mexico (Fig. 1). This article is concerned, however, only with the north-central part of this region - an area of 1.126 million $\mathrm{km}^{2}$, extending from lat. $30^{\circ}$ to $46^{\circ} \mathrm{N}$, and long. $88^{\circ}$ to $100^{\circ} \mathrm{W}$. Much of the information presented here is an outgrowth of a major research endeavor being carried on by the USGS in cooperation with the geological surveys of the twelve northern Midcontinent states (Fig. 2 and Pratt, $1985 a, 1985 b)$. The principal objective in this research is to assess the potential for undiscovered deposits of strategic and critical minerals in a selected but representative part of the Midcontinent.

The area was chosen because it contains several actual or potential world-class mining districts, in both the sedimentary cover rocks and the Precambrian basement. The Precambrian basement is exposed and reasonably well mapped along the north edge (Morey et al., 1982) and in the St. Francois Mountains of Missouri (Kisvarsanyi, 1981). Moreover, geological, mineral-occurrence, geochemical, and geophysical data for several $1^{\circ} \times 2^{\circ}$ quadrangle maps along the southern side of the area have recently been compiled, and assessments of their mineral potential have been made or are in progress (Pratt et al., 1986). Subsurface geological data are available for most of the area through the state surveys, and aeromagnetic and gravity data for much of the area have already been acquired by the USGS.

New insights have been gained by current research that is divided broadly into regional compilations and topical studies. The former represent an "inventory" of several kinds of geological data, most of which already existed in state files or in the minds of their investigators. Data for the Precambrian basement studies have been supplemented by new information and ideas from the USGS investigators. In contrast, the topical studies involve new research, principally in fluid-inclusion geothermometry and geochemistry, sulphur-isotope analysis, and trace-element analysis of drill-hole samples.

\section{Phanerozoic Rocks}

The northern Midcontinent is situated in the central part of the North American craton. The Precambrian basement is exposed in the northern part of the area (Canadian Shield) and at one place farther south, the St. Francois Mountains of southeastern Missouri (see Reed, this issue for a review of the Precambrian). Elsewhere, the basement is covered by Phanerozoic sedimentary rocks, ranging in thickness from their pinchout where they overlap the Precambrian, to some $3700 \mathrm{~m}$ in the Illinois basin and $6000 \mathrm{~m}$ in the Anadarko basin. Throughout much of the region, potentially favorable host rocks, both in the sedimentary cover and in the basement, are shallow enough to be prospected by drilling.

The Phanerozoic rocks are dominantly carbonates with some clastics. A generalized geological map of the region (Fig. 3) reflects the overall horizontality of the sedimentary rocks, modified by the gradually sloping erosional surface from the High Plains on the west toward the Mississippi River valley. The major elements are: overlap of the lower Paleozoic sedimentary rocks onto the Precambrian along the north edge of the area and around the Ozark dome, Pennsylvanian sedimentary rocks in the Illinois basin and (with Permian sedimentary rocks) across the western Interior Lowlands, Cretaceous and Tertiary sedimentary rocks across the Great Plains, and Cenozoic sediments in the Mississippi embayment.

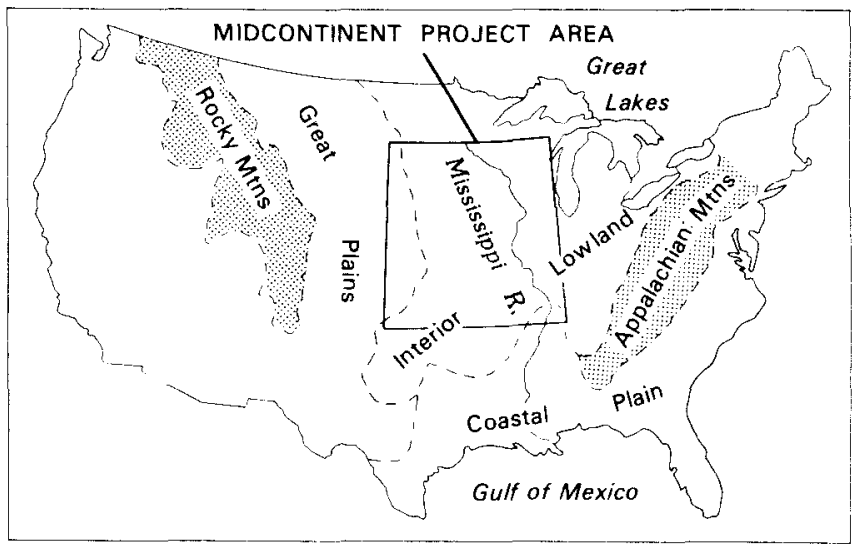

Figure 1: Index map of Midcontinent project area.

Figure 4 is a highly generalized cross section along lat. $40^{\circ} \mathrm{N}$. Cambrian through Mississippian rocks are predominantly carbonates, except for basal sandstones that are thickest in the Illinois basin. The carbonates are mostly dolomites, but limestones dominate the uppermost part of the section east of the Nemaha uplift. The Permian to Pennsylvanian rocks contain about equal amounts of limestones and clastics in the Salina and Forest City basins, but to the east in the Illinois basin they are exclusively clastics 
(shales and minor sandstones). Mesozoic and Tertiary rocks (sandstones and shales) are present only in the Salina basin. The section shows clearly the shallow depth of the basement across the Nemaha uplift. East-west cross sections farther north would show a thinner sedimentary cover, dominated by clastics, whereas sections farther south would show a decreasing thickness of basal clastics and a great thickening of sediments in the Anadarko and Illinois basins (see Masters and Mast, this issue).

\section{The Precambrian Basement}

The exposed and buried basement in the region is a collage of tectono-stratigraphic terranes ranging in age from Archean to Middle Proterozoic (Sims et al., in press, and see Reed, this issue). Eight major terranes have been identified and delineated (Fig. 5). From oldest to youngest, these are: Archean gneiss terrane, Late Archean greenstone-granite terrane, Early Proterozoic Wisconsin magmatic terrane and associated epicratonic sedimentary rocks of the Penokean orogen, Early Proterozoic rhyolite-granite terrane of southern Wisconsin and east-central Minnesota, Early Proterozoic metamorphic and granitoid rocks of the

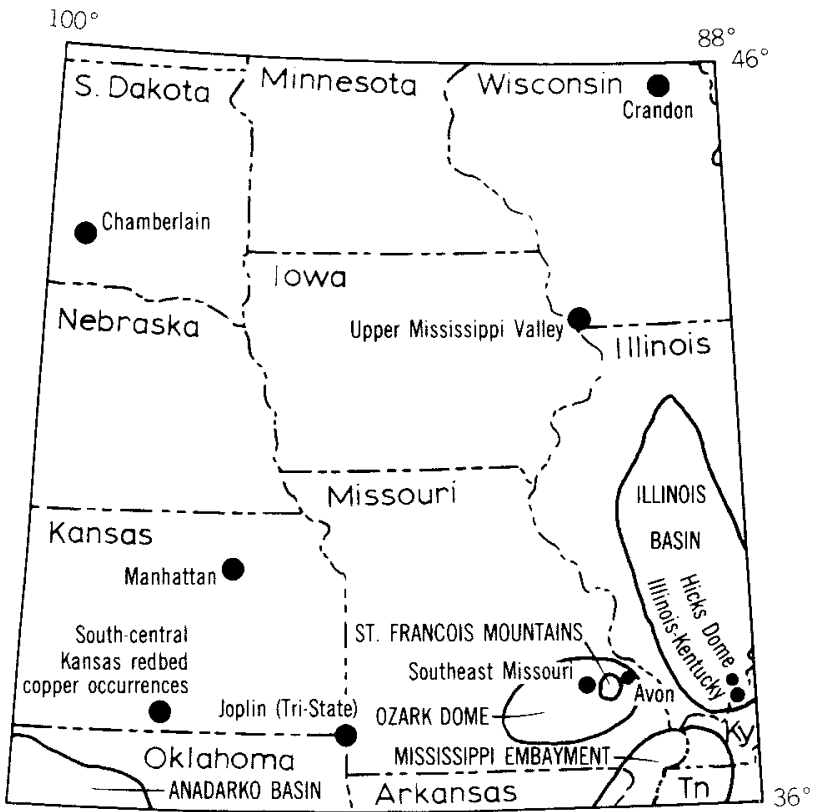

Figure 2: Project area showing localities cited in text. Solid circles indicate mining districts and other key localities. Tn - Tennessee, Ky - Kentucky.

Central Plains orogen, Middle Proterozoic St. Francois granite-rhyolite terrane, Middle Proterozoic Spavinaw granite-rhyolite terrane, and Middle Proterozoic Midcontinent rift system. Other terranes of lesser importance include quartzite of the "Baraboo interval" (Early Proterozoic) and plutons of anorthosite and rapakivi granite of the Transcontinental anorogenic province (Middle Proterozoic). The unit labelled "Granite and associated rocks" on Figure 5 is poorly known because of sparse drill data.

The north-central Midcontinent basement is traversed by numerous northwest-trending tectonic zones interpreted as shears and characterized by cataclastic zones in the basement, by aligned granite and mafic intrusions of Middle Proterozoic age, and commonly, by faulting and folding in overlying Paleozoic rocks. The shears are believed to belong to a family of regional dextral transcurrent faults that are exposed farther north in the Lake Superior region and adjacent Canada. They are potential sites for epigenetic ore deposits.

\section{Mineral Potential of the Phanerozoic Rocks}

Phanerozoic rocks that are potentially favorable for undiscovered mineral deposits include: widespread sedimentary carbonate rocks of Paleozoic age that are potential hosts for Mississippi Valley-type base-metal sulphide, fluorite and barite deposits, Upper Cretaceous shales favorable for sedimentary $\mathrm{Mn}$ deposits, Permian and Triassic red beds ( $\mathrm{Cu}-\mathrm{Ag}$ deposits), marine organic shales (several metals), and alkalic intrusive complexes and kimberlitic diatremes (Ni, Be, REEs, and diamonds).

The most important known mineral deposits in the Phanerozoic rocks are the Mississippi Valley-type (MVT) deposits stratabound with base metal sulphides and locally, fluorite and barite, in carbonate host rocks. The Midcontinent region is the type area for MVT deposits and contains four world-class districts: the Upper Mississippi Valley, Southeast Missouri (Viburnum), and Joplin or Tri-State (OklahomaKansas-Missouri) $\mathrm{Pb}-\mathrm{Zn}$ districts, and the Illinois-Kentucky fluorspar-Pb-Zn district (Fig. 2). These deposits are generally considered to have been formed from heated metal-bearing brines that migrated laterally and upward from source areas in nearby deep basins.

The host rocks in these districts are known to continue to the north and northwest beneath the younger sedimentary rocks and glacial deposits. All the known districts were discovered at or near the surface, and it seems almost certain that additional deposits remain to be discovered at greater depth. To investigate this possibility, we are compiling maps showing the regional distribution of geological factors that are known or suspected to control deposition of MVT ores. These factors include the limestone/dolomite ratio in the Sauk sequence (Upper Cambrian and Lower Ordovician) and in selected parts of the Upper Cambrian and Mississippian rocks, the distribution of shale units that

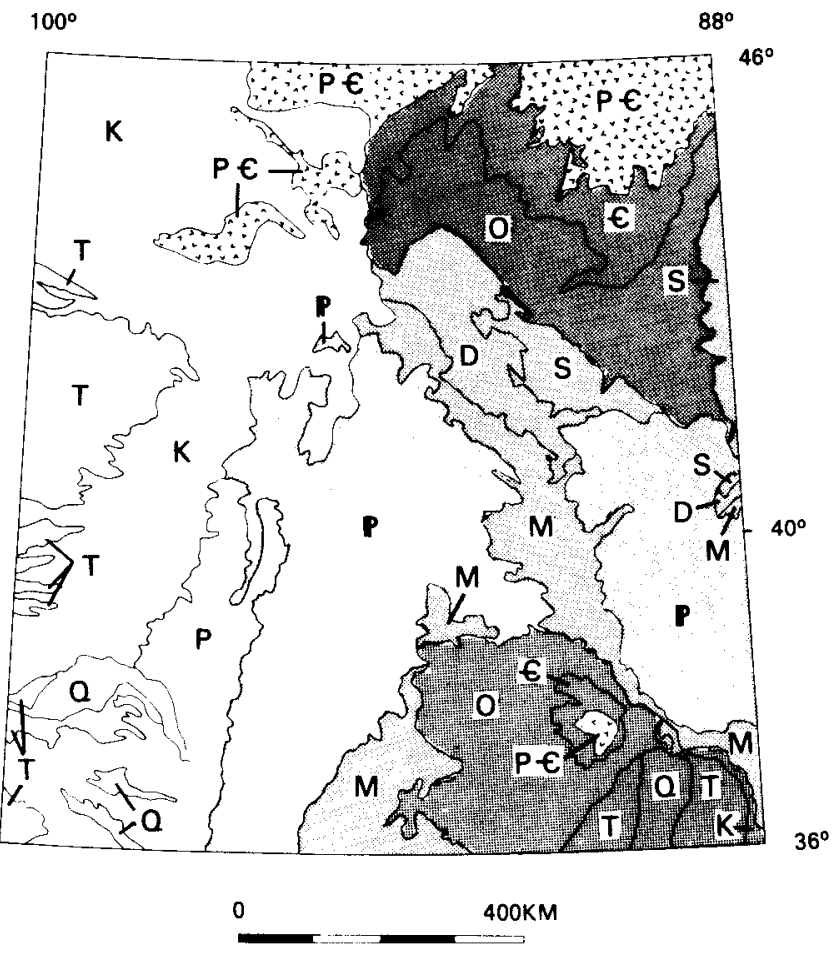

Figure 3: Generalized map of the Midcontinent area. PE-Precambrian, f-Cambrian, O-Ordovician, S-Silurian, D-Devonian, M-Mississippian, P-Pennsylvanian, P-Permian, $K$-Cretaceous, T-Tertiary, Q-Quaternary (Modified from King and Beikman, 1974) 


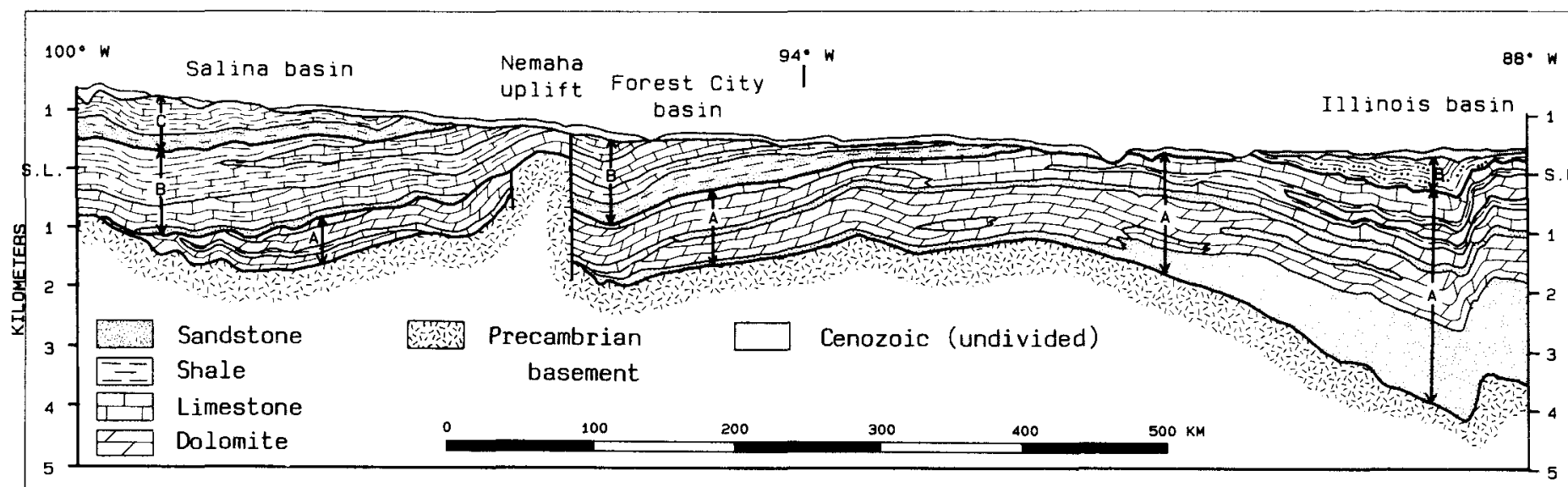

Figure 4: Generalized cross-section along latitude $40^{\circ} \mathrm{N}$. A - Cambrian to Mississippian, B - Permian to Pennsylvanian, C - Mesozoic.

might have impeded the flow of ore-bearing solutions, and inferred groundwater flow systems at several stages in the geological past.

Research is also being conducted on several topics that bear on the genesis of IMVT deposits. These include fluidinclusion, petrographic and geochemical studies (Leach and Kowan, 1986; Rowan et al., 1984; Viets et al., 1984; Mosier, in press) and sulphur isotope investigations (Goldhaber and Viets, 1985). Regional fluid-inclusion and related studies by Leach and his associates have provided new insights into possible mechanisms of origin of these deposits (Leach and Rowan, ibid).

As regards exploration, the pioneering work of Erickson and his colleagues has shown that metal-bearing fluids passing through carbonate rocks tend to leave traces of their metals in the insoluble components of the rocks. They have also demonstrated that semi-quantitative spectrographic analyses of the insoluble residues of these rocks provide an effective, and rapid method of subsurface geochemical sampling and prospecting (Erickson et al., 1981, 1983). To date, however, such geochemical surveys have been restricted to the southern part of the region, and a systematic extension of these surveys northward through the other states is needed in order to establish regional geochemical signatures for the sedimentary formations. Many of these compilations and studies are still underway, and we believe that in the near future we will be able to integrate them into a reasonable genetic model for MVT deposits. This, in turn, should enable us to suggest areas that appear favorable for prospecting.

Cannon and Force (1983) interpreted major sedimentary $\mathrm{Mn}$ deposits as having accumulated in transgressive marine sequences on stable cratonic platforms, with Mn deposition favored during high sea-level stands when the seas tend to become stratified, stagnant, and anoxic. The high stand represented by the Late Cretaceous transgression into the northern Midcontinent provided one such setting, as indicated by sub-economic occurrences of favorable $\mathrm{Mn}$ carbonate concretions or nodules, containing as much as $17 \%$ $\mathrm{Mn}$ in Upper Cretaceous shales in central South Dakota (Fig. 2). Detailed stratigraphic and geochemical studies of the Cretaceous rocks in this area are currently being done by the South Dakota and Minnesota geological surveys to provide a background for possible exploration. We believe that these studies hold excellent promise for determining the potential for economically significant Mn deposits.

Small red bed-associated $\mathrm{Cu}(-\mathrm{Ag})$ deposits occur in Permian and Triassic host rocks in central to southwestern Oklahoma and south-central Kansas (Johnson and Croy, 1976; Ripley et al., 1980). Subsurface continuations of the same formations
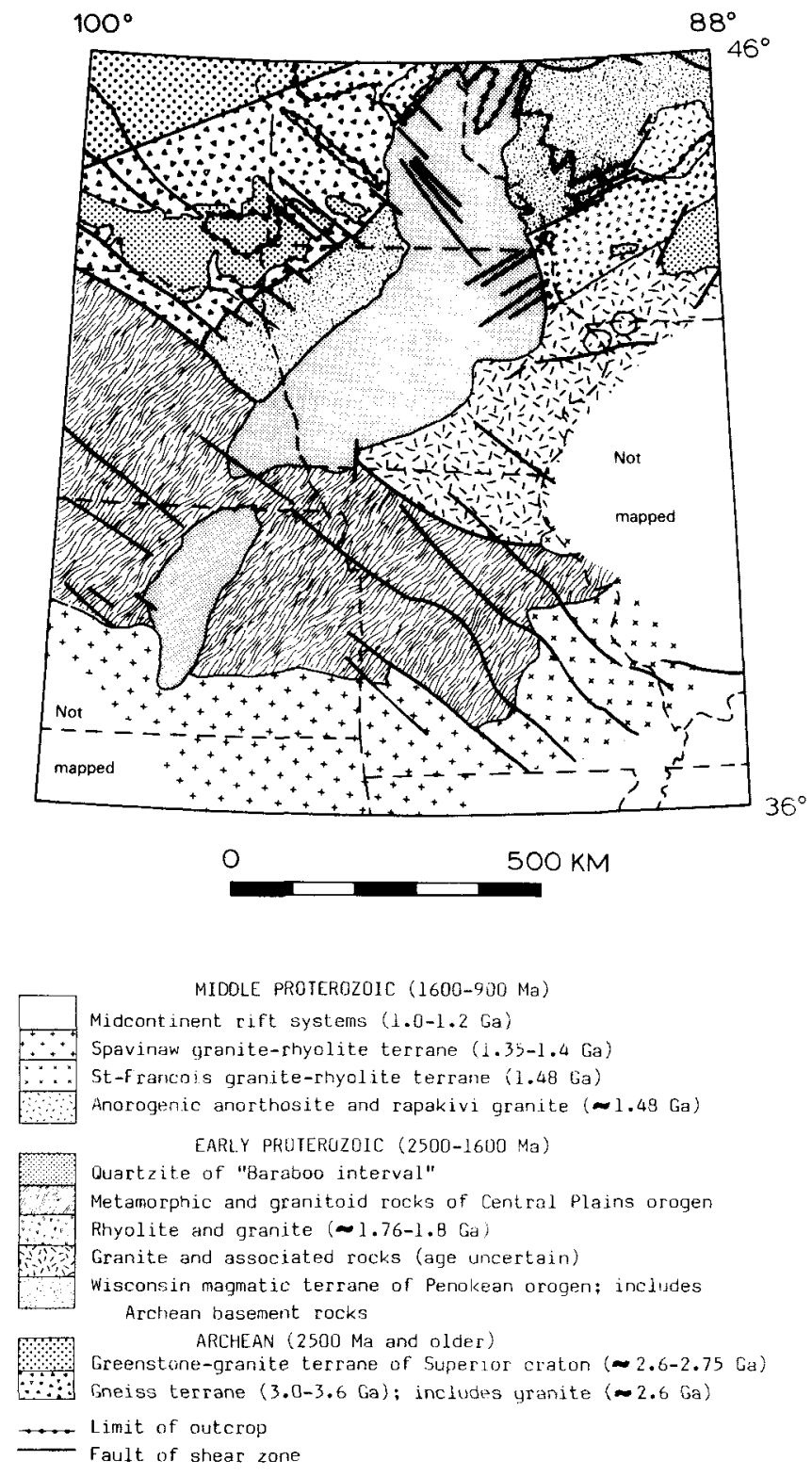

Figure 5: Precambrian basement terranes (from Sims, 1985). 
in these and adjacent states have a potential for additional deposits of these types. Current exchanges of data and theories on the genesis of the deposits, together with further research, may help to identify targets for exploration.

Marine organic shales may contain anomalously high amounts of $\mathrm{Ag}, \mathrm{Zn}, \mathrm{Cr}, \mathrm{V}, \mathrm{Mo}, \mathrm{Ni}$ and Co (Poole and Desborough, 1983). Within the Midcontinent region, the Chattanooga Shale of Late Devonian and Early Mississippian age is metal-rich (Vine and Tourtelot, 1970, p. 266), as are certain Pennsylvanian black shales (Coveney, 1981). A reconnaissance survey is planned to determine the extent, thickness, and metal content of the Chattanooga and its equivalent formations, as well as other, less well known organic shales to determine their potential for these metals.

Alkalic intrusive complexes occur in the Midcontinent at several places, most notably at Hicks dome in southern Illinois, near Avon in southeastern Missouri, and near Manhattan in northeastern Kansas (Fig. 2). At the cryptovolcanic center at Hicks dome, a cluster of mineralized explosion breccias in Devonian rocks contain $\mathrm{Th}, \mathrm{Nb}, \mathrm{Be}$ and rare-earth minerals, as well as fluorite, barite, and sphalerite that are thought to be related to dikes of alkalic peridotite, lamprophyre, and kimberlite (Heyl et al., 1966, p. B(0-B 11 . At Avon, nearly a hundred kimberlitic diatremes and alkalic peridotite dikes have been identified in Upper Cambrian and Lower Ordovician host rocks within an area of about $200 \mathrm{~km}^{2}$; some of these contain galena, sphalerite, barite, fluorite, and trace amounts of $\mathrm{Th}, \mathrm{Nb}, \mathrm{Cr}$, $\mathrm{Y}$ and REE.

Near Manhattan, at least six kimberlite diatremes intrude Lower Permian sedimentary rocks in a $400-\mathrm{km}^{2}$ area (Brookins, 1970). Other kimberlite occurrences are known in these and several other states in the Midcontinent. Their significance is not so much in the resources they themselves contain, which are fairly well known, but in the implication that there may be undiscovered kimberlitic and perhaps diamond-bearing diatremes elsewhere in the Midcontinent, in the vast subsurface/subglacial areas that have not yet been adequately explored.

\section{Mineral Potential of the Precambrian Basement Rocks}

We believe the Precambrian basement rocks of this region have a high potential for undiscovered mineral resources, because many of the Precambrian terranes are favorable for ore generation. Parts of the region with exposed Precambrian rocks - the Lake Superior region in the north and the Southeast Missouri district in the southeast - are major mineral-producing areas that together have yielded ores, mainly of $\mathrm{Fe}$ and $\mathrm{Cu}$, valued at several billion dollars. A further positive factor has been the relatively recent discovery in the Lake Superior region of as yet unmined deposits containing large resources of $\mathrm{Zn}, \mathrm{Cu}, \mathrm{Ni}, \mathrm{Co}$ and Pt. Moreover, in about two-thirds of the northern Midcontinent area, the basement is less than $900 \mathrm{~m}$ below the surface, another "plus" for exploration.

Four major geological terranes known to contain substantial mineral resources extend into the subsurface. The first, the Late Archean greenstone-granite terrane in the buried basement of North and South Dakota, could host massive sulphide deposits up to 5 million tons in size, stratiform and vein-type gold, Algoma-type iron-formation, and possibly other types of deposits. Felsic volcanic rocks of tholeiitic affinity would be the most favorable host rocks for sulphide and gold deposits.

The second, the Early Proterozoic Wisconsin magmatic terrane, is known to contain at least four volcanic-hosted massive sulphide deposits of future economic importance, the largest of which (Crandon, Wisconsin) contains about 60 million tons of $\mathrm{Cu}-\mathrm{Zn}$ ore. Other known deposits are smaller, about 5 million tons. Gold may also occur in this terrane.
The third, the Middle Proterozoic St. Francois graniterhyolite terrane, contains large deposits of $\mathrm{Fe}$ and $\mathrm{Cu}-\mathrm{Fe}$ and apparently smaller deposits of $\mathrm{Sn}, \mathrm{Wo}, \mathrm{Ag}, \mathrm{Pb}$ and $\mathrm{Sb}$. Both the St. Francois and Spavinaw granite-rhyolite terranes provide a tectonic environment broadly similar to that of the immense Olympic Dam $\mathrm{Cu}-\mathrm{Au}-\mathrm{U}$ deposit in southern Australia, and they deserve consideration for exploration.

The fourth terrane, rocks of the Middle Proterozoic Midcontinent rift system, contains large stratiform voleanichosted and sediment-hosted $\mathrm{Cu}$ deposits and the very large but as yet unmined gabbro-hosted $\mathrm{Cu}-\mathrm{Ni}$ deposits of the Middle Proterozoic Duluth Complex. Iron oxide-rich mafic intrusive rocks could contain platinum-group metals. In recent years, the sedimentary rocks have been targeted as potential sources of petroleum (Dickas, 1986).

Other terranes, by analogy with similar rocks elsewhere in the world that are known to contain valuable ore deposits, are also potentially ore bearing. The quartzite of the "Baraboo interval" possibly could overlie unconformity-type uranium deposits. Rocks of the Central Plains orogen could contain base-metal sulphide and tungsten deposits. Contrary to current exploration philosophies, the Archean gneiss terrane could possibly host deposits of base and precious metais.

\section{Conclusion}

The potential for mineral deposits in the subsurface of the Midcontinent has not yet been adequately tested - partly because of a lack of data and partly because of a traditional reluctance to prospect at depths exceeding a few hundred metres. With the data now a vailable, and with the evolution of new concepts of the processes and controls of ore formation, new prospecting models, and improved techniques, we believe that both the Precambrian basement and the sedimentary cover rocks of the Midcontinent offer promise for the existence and discovery of several different types of significant mineral deposits.

Dr. W.P. Pratt is a research geologist with the USGS in Denver (MS 905, Box 25046, Federal Center, Denver, CO 80225, U.S.A.). For the past twelve years he has coordinated several projects devoted to regional assessment of mineralresource potential, the CUSMAP and Midcontinent projects described here. He is currently Editor of the SEG pages in Economic Geology.

Dr. P.K. Sims has worked with the USGS (Denver, Colorado) since 1946, except for a period (1961-73) as Director of the Minnesota Geological Survey and Professor of Geology at the University of Minnesota. His primary interest is the petrology, structure and mineral deposits of Precambrian rocks. He was the Secretary of the IUGS Subcommission on Precambrian Stratigraphy from 1975 to 1984 .
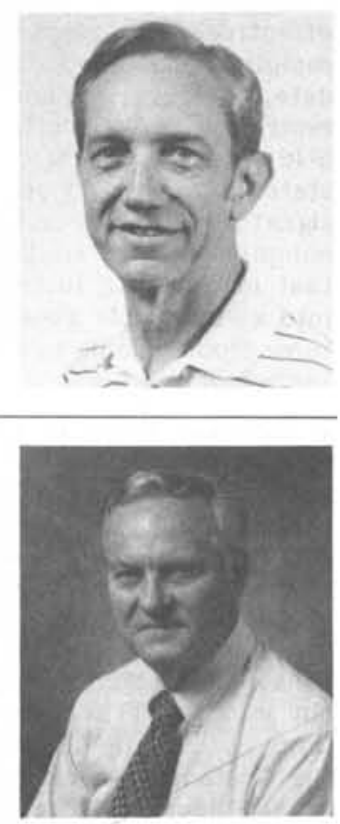


\section{References}

Brookins, D.G., 1970. Kimberlite at Winkler Crater, Kansas. Ceological Society of America Bulletin, v. 81, no. 2, p. 541-545.

Cannon, W.F. and Force, E.R., 1983. Potential for high-grade shallow-marine manganese deposits in North America. In: Shanks, W.C., III (ed.), Unconventional mineral deposits (Cameron volume). American Institute of Mining, Metallurgical, and Petroleum Engineers, New York, p. 175-i 89 .

Coveney, R.M., Jr., 1981. Thin black Pennsylvanianage shales of the Mid-continent U.S., a neglected metallic resource? Ceological Socjety of America, Abstracts with Programs, v. 13 , no. 7 , p. 432 , summary only.

Dickas, A.B., 1986. Comparative Precambrian stratigraphy and structure along the Mid-Continent rift. American Association of Petroleum Geologists Bulletin, v. 70 , no. 3, p. 225-238.

Erickson, K.L., Mosier, E.L., Odland, S.K. and Erickson, N.S., 1981. A favorable belt for possible mineral discovery in subsurface Cambrian rocks in southern Missouri. Economic Geology, v, 76, no. 4, p. 921-933.

Erickson, R.L., Mosier, E.L., Viets, J.G., Odland, S.K. and Erickson, M.S., 1983. Subsurface geochemieal exploration in carbonate terrane - Midcontinent, U.S.A. In: Kivarsanyi, G. (ed ) International confer-

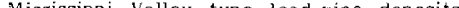
ence on Mississippi
University of Missouri-Rolla, p. 575-583.

Goldhaber, M.B. and Viets, J.G., 1985. Isotope evidence for sulfur sources for the Viburnum Trend of lead-zine mineralization, southeast hissouri. Geological Society of America, Abstracts with Programs, v. 17, no. 7, p. 594, summary only.

Heyl, A.V., Brock, M.R., Jolly, J.L. and Wells, C.E., 1966. Regional structure of the Southegst Missouri and Mlinois-Kentucky mineral districts. U.S. Geological Survey Bulletin 1 202-B, D. B1-B20.
Johnson, K.S. and Croy, R.L. (eds.), 1976. Stratiform copper deposits of the Midcontinent region: a symposium. Oklahoma Geologieal Survey Circular $77,99 \mathrm{p}$.

King, P.B. and Beikman, H.M., 1974 (1975). Geologic map of the United States (exclusive of Alaska and Hawaii). U.S. Geological Survey map, seale 1:2,500,000. Kisvarsanyi, E.B., 1981. Geology of the Precambrian St. Francois terrane, southeastern Missouri. Missouri Department of Natural Resources, Division of Geology and Land Survey, Report of Investigations 64, $58 \mathrm{p}$.

Leach, D.L. and Rowan, E.L., 1986. Genetic link between Ouachita foldbelt tectonism and the inississippi Valley type lead-zinc deposits of the Ozarks. Geology, v. 14, no. 11, p. 931-935.

Morey, G.B., Sims, P.K., Cannon, W.F., Mudrey, M.G., Jr. and Southwick, D.L., 1982. Geologic map of the Lake Superior region; Minnesota, Wisconsin, and northern Michigan. Minnesota Geological Survey State Map Series S-13, scale $1: 1,000,000$.

Mosier, E.L., in press. Geochemistry of the basal Cambrian sandstones in parts of Missouri, Arkansas, and Ransas. In: Martin, J.A. and Pratt, W.P. (eds.), Geology and mineralresource potential of the Springfield $1^{\circ} \times 2^{\circ}$ quadrangle, Missouri, as appraised in September 1985 . U.S. Geological Survey Bulletin.

Poole, F.G. and Desborough, G.A., 1983. Metal concentrations in some marine black shales of the United States, In: Shanks, W.C., III (ed.), Unconventional mineral deposits (Cameron volume) American Institute of Mining, Metallurgical, and Petroleum Engitute of Mining, Metallurgical

Pratt, W.P., 1985a. Midcontinent strategic and critical minerals project. Geological Society of America, Abstracts with Programs, v. 17, no, 7, p. 692-693, Abstracts with
summary only.

Pratt, W.P. (ed.), 1985b. The Midcontinent strategic and eritical minerals project; objectives and status,
October 1985. U.S. Geological Survey Open-File Report 85-0597, $16 \mathrm{p}$.

Pratt, W.P., Erickson, K.L., Jenson, S.K. and Hastings, D.A., 1986. The Rolla and Springfield, Missouri CUSMAP resource assessments. In: Cargill, S.M. and Green, S.B. (eds.), Prospects for mineral resource assessments of public lands: Proceedings of the Leesburg workshop. U.S. Geological Survey Circular 980 p. $140-159$.

Ripley, E.M., Lambert, M.W. and Berendsen, P., 1980. Mineralogy and paragenesis of red-bed copper mineralization in the Lower Permian of south central Kansas. Economic Geology, v. 75, no. 5, p. 722-729.

Rowan, E.L., Leach, D.L. and Viets, J.G., 1984. Evidence for a Late Pennsylvanian-Early Permian regional thermal event in Missouri, Kansas, Arkansas, and Oklahoma. Ceological Society of America, Abstracts with Programs, v. 16, no. 6, p. 640, abstraet only.

Sims, P.K. (compiler), 1985. Precambrian basement map of the northern Midcontinent, U.S.A. U.S. Geologieal Survey Open-File Report 85 0604, scale $1: 1,000,000,16 \mathrm{p}$.

Sims, P.K., Kisvarsanyi, E.B. and Morey, G.B., in press. Geology and metallogeny of Arehean and Proterozoic basement terranes in the northern Midcontinent, U.S.A. - an overview. U.S. Geological Survey Bulletin 1815 .

Viets, J.G., Rowan, E.L. and Leach, D.L., 1984. Composition of fluids extracted from sphalerite, galena, and dolomite in Mississippi Valley-type deposits of the midcontinent; implications for the origin of the fluid. Geological Society of America, Abstracts with Programs, v. I6, no. 6, p. 682, summary only.

Vine, J.D. and Tourtelot, E.B., 1970. Geochemistry of black shale deposits; a summary report. Economic Geology, v. 65, no. 3, p. 253-272.

An intensive in-service course for professional geologists on:

\title{
PROCESSES IN CARBONATE ENVIRONMENTS
}

\section{Organized by: \\ Julia A. E. B. Hubbard (King's College (KQC), London University) $\&$ \\ Robin G. C. Bathurst (Liverpool University)}

\section{OBJECTIVES}

The course is organized for the benefit of professional geologists concemed with the genesis and distribution of carbonate rocks in all their aspects sedimentology, biology, petrography and diagenesis. Main emphasis will be placed on the handling of both recent and ancient materials with particular reference to those aspects which cannot be gleaned from a study of the literature. In accepting participants the organizers will aim at balancing the proportions of those with industrial, survey and academic experience. Research students should have a minimum of one year's graduate experience. The number of participants will be limited to about 34

\section{LOCATION}

Wye College, University of London, Nr. Ashford, Kent, TN25 SAH

How to book:

All applications should be accompanied by a brief curriculum vitae and statement of geological interests. These should be addressed to the convenor.

\author{
DR. JULIA HUBBARD \\ THE GEOLOGICAL STUDIES GROUP \\ KING'S COLLEGE LONDON \\ THE STRAND \\ LONDON WC2R 2LS
}

\section{Aided by:}

Dr. Richard Bromley

University of Copenhagen, Denmark

Cretaceous chalks; trace fossils; bioerosion.

Dr. Tony Dickson

University of Cambridge.

Calcite cementation; cathodoluminescence

Carboniferous and Jurassic limestones.

Dr. Mateo Esteban

Erico, U.K.

Professor Eric Flügel

University of Erlangen. Germany.

Microfacies.

Professor Jake Haneock

College of Science and Technology.

Cretaceons: Stratigraphy; Chalks.

Dr. Jim Marshall

University of Liverpool

Dr. John Miller

University of Edinburgh.

Carboniferous mudmound facies.

Professor Bruce Purser

University of Paris, France.

Jurassic sheif carbonates: Recent of Mesopotamian Gulf

Petroleum geology.

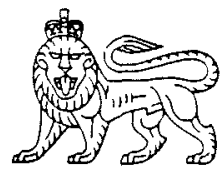

Dr. Tony Ramsay

University Coliege. Swansea.

Carbonate depositional systems.

Professor Wolfgang Schinger

The Free University. Amsierdam. The Netherlands. Platform carbonates

\section{Professor Johannes Schroeder}

University of Kiel. Germany.

Cartronate diagenesis; Reef dynamics:

\section{Professor Walther Schwarzacher}

Queen's University. Belfas

Cyclic sedimentation: Shelf cartronates:

Models of sedimentation; Quantitative stratigraphy.

Dr. Peter Westbroek

University of Leiden. The Netherlands.

Biopolymers and immunological characterization

of biomineralization.

An industrial speaker

Applications of porosity evolution to

subsurface conditions.

COURSE FEE:

Industrial and Government services: $£ 750$

Academic staff:

$\mathbf{1 3 0 0}$

Full time research students:

TEL: 01-837 0020 TELEX 24555 BLPESC 